\title{
PERANCANGAN APLIKASI PENCARIAN RUTE TERDEKAT JASA BINATU ONLINE BERBASIS ANDROID DENGAN MENGGUNAKAN METODE DIJKSTRA
}

\section{ANA FARIDATUN NAFIAH}

Teknik Informatika, Fakultas Teknik

Universitas Maarif Hasyim Latif, Sidoarjo, Indonesia

e-mail : ana-faridatun-nafiah@student.umaha.ac.id

\section{ABSTRAK}

Revolusi industri 4.0 saat ini menupakan tahap perkembangan manusia yang semakin berkembang pesat, dengan perkembangan ini haruslah dimanfaatkan sebaik mungkin. Seperti halnya pemanfaatan teknologi untuk jasa binatu, dimana membantu pengguna aplikasi dalam menemukan lokasi jasa binatu terdekat dari pengguna, memberikan informasi jasa binatu dan memberikan rute terdekat dengan metode shortestpath yaitu metode dijkstra. Aplikasi yang membantu meringankan aktifitas-aktifitas manusia dalam permasalahan dengan jasa binatu yang cenderung memilih sesuatu yang lebih cepat, sederhana, efisien dan dapat membantu dimanapun serta kapanpun saat dibutuhkan ketimbang harus bersusahsusah melakukannya. Aplikasi yang menambahkan didalamnya teknologi GPS yaitu Global Positioning System dan MySQL sebagai media penyimpanan data internet yang digunakan sebagai database.

Kata kunci: global positioning system, jasa binatu online, shortestpath dijkstra

\section{PENDAHULUAN}

Revolusi industri 4.0 untuk saat ini merupakan tahap perkembangan manusia yang semakin berkembang pesat, dimana besarnya peran internet dalam menjembatani perpindahan informasi dari berbagai tempat tanpa dibatasi ruang dan waktu untuk menggunakannya adalah penyebab dari pesatnya revolusi industri $4.0 \mathrm{itu}$ sendiri. Kecenderungan memilih sesuatu yang lebih cepat, sederhana, efisien dan dapat membantu dimanapun serta kapanpun saat dibutuhkan ketimbang harus bersusah-susah melakukannya.

Seperti halnya pemanfaatan teknologi untuk jasa binatu. Dimana permasalahan yang biasa terjadi antara konsumen dengan jasa binatu adalah kurangnya pengetahuan konsumen tentang lokasi jasa binatu yang ada disekitarnya, informasi jasa binatu yang kurang diketahui oleh konsumen dan rute terdekat yang dapat digunakan konsumen untuk menuju jasa binatu. Dimana khusus wilayah Ngelom, Taman Sidoarjo banyak sekali jasa binatu yang ada akan tetapi memiliki permasalahan tersebut, Oleh karena itu aplikasi ini akan tertuju di wilayah Ngelom, Taman - Sidoarjo saja.

Untuk itu perlunya menambahkan teknologi untuk menjembatani antara konsumen dan jasa binatu serta menyelesaikan permasalahnnya. Aplikasi yang menambahkan di dalamnya teknologi GPS yaitu Global Positioning System untuk mendeteksi lokasi binatu di sekitarnya dan menggunakan metode ShortestPath Dijkstra menunjukan rute terdekat ke binatu tersebut.
MySQL sebagai media penyimpanan data internet yang digunakan sebagai database dan MySQL.

Dengan permasalahan yang sebelumnya mengenai binatu akan terselesaikan dimana aplikasi ini dapat membantu Pengguna menemukan binatu mana yang terdekat dari lokasinya, memberikan rute terdekat, memberikan informasi lengkap mengenai binatu dan dapat membantu Pengguna dimanapun dan kapanpun dengan efisien dan modern sesuai perkembangan revolusi 4.0.

\section{METODE PENELITIAN}

\section{Flowchart}

Berikut urutan-urutan proses kerja aplikasi dan hubungan antara suatu proses dengan proses lainnya, dimana aplikasi pencarian rute terdekat jasa binatu online berbasis android ini memiliki 2 tampilan berbeda antara konsumen dan jasa binatu disesuaikan dengan kebutuhan masing-masing pengguna.

Flowchart gambar 1 adalah menu utama pada konsumen, dijelaskan bahwa ada 3 tahapan atau menu yang ada di dalam aplikasi yang masing-masing memiliki fungsi dan tujuan berbeda yaitu berupa mencari dengan peta, memberikan tips dan trik untuk user dalam mencuci supaya lebih ringan dan mudah serta menu untuk memberi bintang atau peringkat kepada jasa binatu setelah memakai jasanya. Tahapan/menu yang nantinya terpilih akan 
dilanjutkan ke tahap berikutnya yang aplikasi sudah siapkan.

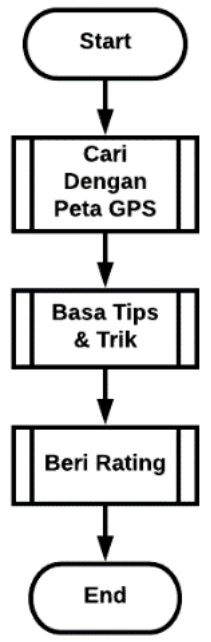

Gambar 1. Flowchart Menu Utama Konsumen Binatu

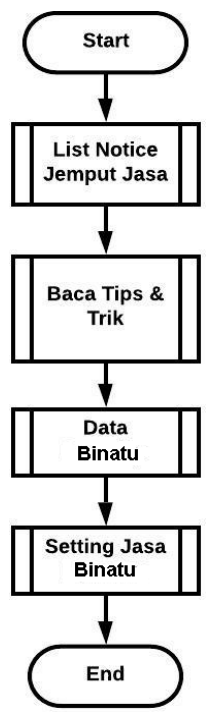

Gambar 2. Menu Utama Jasa Binatu

Untuk menu utama pada jasa binatu dapat dilihat pada diatas bahwa pada menu utama jasa binatu berbeda dengan menu utama konsumen binatu, yaitu tidak ada pencarian dan rating yang ada adalah notice jemput jasa, data binatu dan pengaturan ini sesuai dengan kebutuhan dan kepentingan keduanya yang berbeda. Ini disesuaikan dengan keperluan jasa binatu dalam menjalankan aplikasi dengan mudah, sederhana dan bermanfaat.

Flowchart gambar 3 adalah urutan-urutan pada aplikasi menu utama konsumen. Disini akan muncul lokasi jasa binatu terdekat dari pengguna, menampilkan informasi jasa binatu yang dipilih oleh konsumen dan nantinya dapat melakukan pemesanan dengan mengirimkan notice ke jasa binatu terpilih dan dapat berangkat sendiri ke tempat binatu dengan pencarian rute terdekat jika memang binatu tersebut tidak melayani jasa antar jemput.

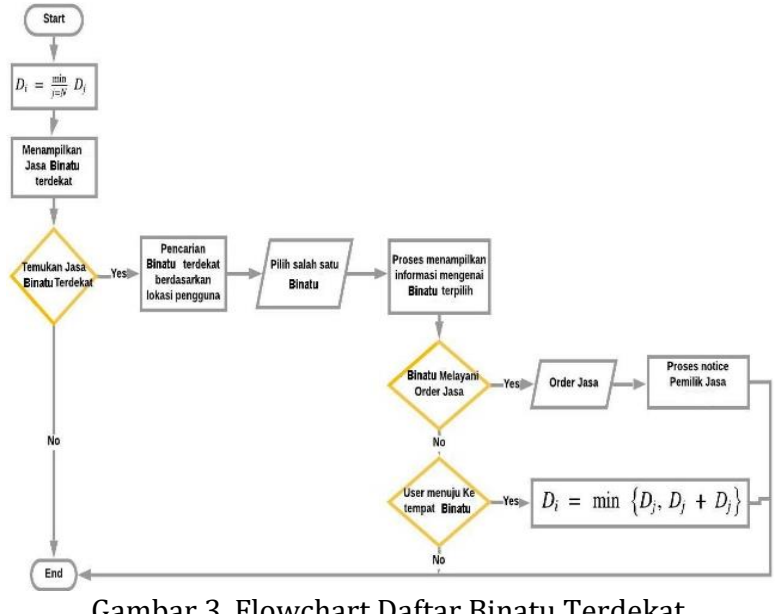

Gambar 3. Flowchart Daftar Binatu Terdekat

\section{Jalur Terpendek (Shortestpath Problem)}

ShortestPath adalah pencarian jalur/rute terdekat dari node satu ke node lainnya dengan biaya yang paling kecil yang dihasilkan dari suatu jalur/rute adalah minimum node awal menuju node tujuan. Bagaimana kita mencari sebuah jalur/rute adalah dengan mencari atau menentukan lintasan terpendek pada suatu graph tersebut untuk diminimumkan bobot sisi pembentuk jalurnya.

Macam-macam algoritma pencarian jalur/rute terdekat yang dapat digunakan seperti algoritma Greedy, Algoritma Dijkstra, Algoritma Bellman-Ford, Branch and Bound (B\&B), Algoritma Koloni Semut, Algoritma Floyd-Walshall, Algoritma Genetik, Algoritma A*, Algoritma PHA, Algoritma Johnson, Algoritma Exhaustic Search, Algoritma UCS (Uniform Cost Search), Algoritma Perkalian Matriks dan Algoritma Pengkoreksian Label (Label Correcting)

\section{Algoritma Dijkstra}

Pada tahun 1959 Edsger Wybe Dijkstra telah menemukan dan menyelesaikan masalah-masalah tentang Shortest Path Problem atau jarak terpendek pada sebuah graf berarah dan sering disebut dengan Algoritma Dijkstra. Algoritma dijkstra dalam pencarian solusi jarak terdekat menggunakan prinsip Greedy yaitu untuk mencari solusi optimum setiap langkah yang dilewati dengan tujuan memperoleh solusi terbaik pada langkah berikutnya yang akan mengarahkan kepada solusi optimum.

Proses pencarian jalur/rute terdekat dari node satu ke node lainnya dengan biaya yang paling kecil yang dihasilkan dari suatu jalur/rute pada suatu rute dalam sebuah jaringan adalah proses perhitungan rute terpendek. proses pemeliharaan-pemeliharaan node dan proses pemberian label merupakan dua macam proses dalam perhitungan rute terpendek. Metode pada setiap node dalam jaringan yang diberikan identifikasi adalah metode pemberian label. Pada 
algoritma yang sebagian besar perhitungan rute terpendek.

Metode ini menurut penulis dapat digunakan untuk aplikasi pencarian rute terdekat jasa binatu online berbasis android yang berguna mendeteksi binatu-binatu terdekat dari pengguna dan mendapatkan informasi mengenai binatu didalamnya. Terdapat beberapa notasi utama dalam pengerjaan Algoritma Dijkstra ini.

1. Dalam bentuk suatu array/himpunan $N$ proses inisialisasi dirumuskan dengan :

$$
\begin{aligned}
& N=\{s\} \\
& D_{j}=C_{S J}, \forall_{J} \neq s \\
& D_{S}=0
\end{aligned}
$$

Maka pada tahap inisialisasi ini nilai $D_{j}$ dimasukan nilai yang sebenarnya. Akan dianggap tak terdefinisi jika secara langsung tidak tersambung dan untuk jarak $D_{s}$ sudah pasti bernilai 0 .

2. Temukan Simpul Tetangga (Node Selain Sumber)

$$
D_{i}=\frac{\min }{j \in N} D_{j}
$$

Untuk mengetahui jarak terdekat maka perlu memasukan node $i$ pada himpunan $N$ berdasarkan pada jarak terkecil dengan node $S$, dan iterasi akan berhenti jika seluruh node sudah dihitung menggunakan rumus tersebut.

3. Update Untuk Setiap $j \in N$

$$
D_{j}=\min \left\{D_{j}, D_{i}+C_{i j}\right\}
$$

Untuk setiap node $j$ diperbahui nilainya yang paling kecil yaitu antara nilai $D_{j}$ sebelumnya dengan hasil penjualan $\left(D_{i}+C_{i j}\right)$ yaitu penjumlahan jarak $s$ ke node $i$ dengan jarak sebenarnya dari node $i$ ke node $j$.

\section{Usecase Diagram}

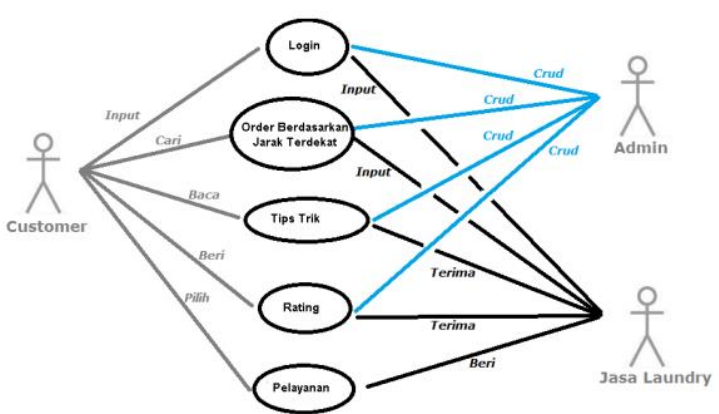

Gambar 4. Use Case Diagram Aplikasi

Usecase aplikasi ini menggambarkan bahwa aplikasi jasa binatu online berbasis android ini memiliki 3 aktor yaitu customer, jasa binatu dan admin yang pada setiap aktornya menggambarkan sebuah sistem yang fungsionalitas sesuai harapan program sistem.

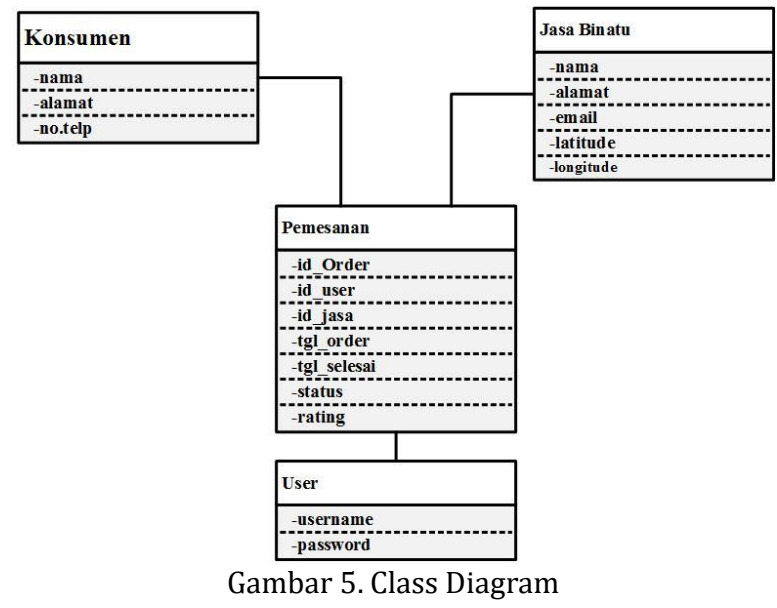

Dapat dilihat pada usecase diagram diatas menunjukan model statis yang digambarkan dengan struktur dan penjelasan class serta hubungannya antara class pada login dari 3 aktor aplikasi binatu online berbasis android. Antara konsumen, admin dan jasa binatu melalui proses login yang sama.

\section{Kamus Data}

Berikut data dictionary aplikasi yang terdiri dari 3 bentuk yaitu data user, data order dan data jasa. Yang saling berhubungan antara konsumen dan jasa binatu.

Tabel 1. Kamus Data Konsumen

\begin{tabular}{l|l|l|l|}
\hline \multicolumn{1}{|c|}{ data_user } \\
\hline \multicolumn{1}{|c|}{ Field } & \multicolumn{1}{c|}{ Type } & \multicolumn{1}{c|}{ Size } & \multicolumn{1}{c|}{ Ket } \\
\hline user & varchar & 100 & Primary Key \\
\hline email & varchar & 50 & \\
\hline password & varchar & 5 & \\
\hline no_telp & varchar & 14 & \\
\hline
\end{tabular}

Kamus Data tabel 1 merupakan kamus data yang dimiliki oleh konsumen yang menjelaskan

\begin{tabular}{|c|c|c|c|}
\hline Field & Type & Size & Ket \\
\hline id & int & 5 & Primary Key \\
\hline nama_laundry & varchar & 100 & \\
\hline telp_laundry & varchar & 100 & \\
\hline rating_laundry & int & 5 & \\
\hline email_laundry & varchar & 100 & \\
\hline password_laundry & varchar & 6 & \\
\hline latitude & float & & \\
\hline longitude & float & & \\
\hline
\end{tabular}
mengenai arus data dalam konsumen yang akan diuraikan secara lengkap mulai dari nama user, email, password dan nomor telp.

Tabel 2. Kamus Data Jasa Binatu

Untuk kamus data jasa binatu hampir sama dengan konsumen hanya menambahkan beberapa 
point yang dibutuhkan jasa binatu seperti rating, latitude dan longitude. Hal ini digunakan untuk informasi lokasi jasa binatu dan informasi yang akan ditampilkan nantinya tentang rating.

Tabel 3. Kamus Data Jasa

\begin{tabular}{l|l|l|l|}
\multicolumn{1}{|c|}{ data_order } \\
\hline \multicolumn{1}{|c|}{ Field } & \multicolumn{1}{c|}{ Type } & \multicolumn{1}{c|}{ Size } & \multicolumn{1}{c|}{ Ket } \\
\hline id_order & int & 5 & Primary Key \\
\hline id_user & varchar & 100 & \\
\hline id_jasa & int & 5 & \\
\hline tg|order & date & & \\
\hline tg__selesai & date & & \\
\hline status & text & & \\
\hline rating & int & 5 & \\
\hline
\end{tabular}

Untuk kamus data jasa binatu hampir sama dengan konsumen hanya menambahkan beberapa point yang dibutuhkan jasa binatu seperti rating, latitude dan longitude.

\section{HASIL DAN PEMBAHASAN}

\section{Implementasi Sistem}

Sesuai dengan yang dijelaskan pada bagian analisis dan perancangan sistem bahwa aplikasi akan dijalankan oleh konsumen dan jasa-jasa binatu yang mana memiliki tampilan yang berbeda sesuai kebutuhan masing-masing.

\section{Tampilan Antar Muka}

Pada bagian ini penulis akan menjelaskan tentang tampilan yang dimiliki oleh konsumen dan jasa binatu. Dimana langkah pertama yang dilakukan adalah login. Yang dapat dilihat pada Gambar 6 Login yang terhubung dengan basis data MySQL dan akan tersimpan dan selanjutnya dikelola oleh admin. Setelah melakukan login konsumen atau jasa binatu dapat masuk pada menu utama. Jika belum terdaftar sebelumnya, dapat melakukan pendaftaran terlebih dahulu. Dapat dilihat pada Gambar 7 Registrasi Konsumen dan Gambar 8 Registrasi Jasa Jasa binatu.

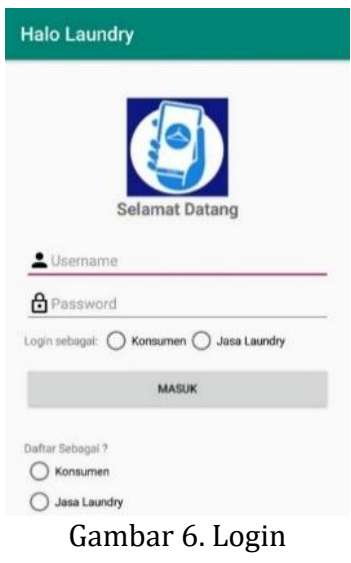

Data yang nanti dimasukan/terinput akan tersimpan di sistem yang akan dikelola oleh admin sebagai file aplikasi. Pilihan yang diambil oleh Pengguna akan menampilan form registrasi yang berbeda, jika masukan yang diisi sudah benar maka akan masuk pada menu utama, sebaliknya jika masih salah atau data sudah ada sebelumnya maka sistem tidak akan berjalan atau buka menu utama aplikasi.

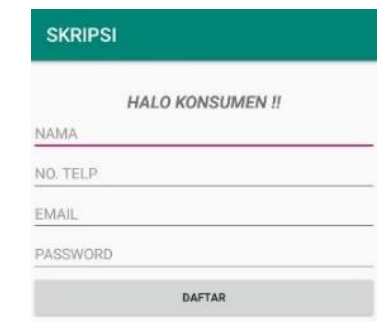

Gambar 7. Registrasi Konsumen

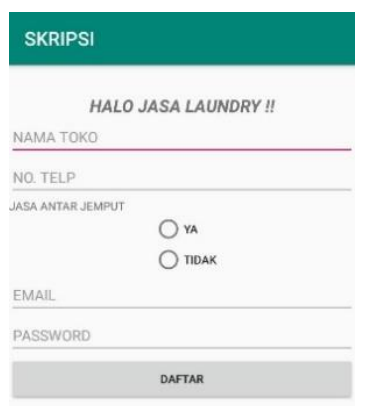

Gambar 8. Registrasi Jasa Binatu

Setelah mengisi registrasi dan tervalidasi maka akan masuk pada menu utama, Menu utama ini juga berbeda antara konsumen dan jasa binatu sebagai berikut;

1. Konsumen

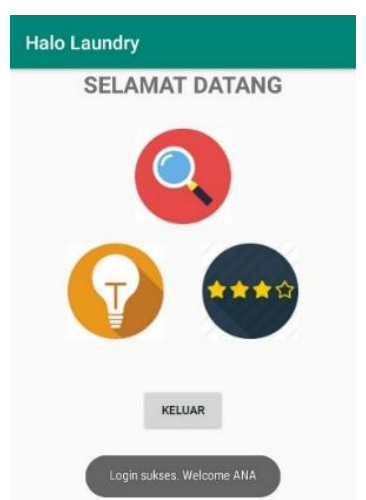

Gambar 9. Menu Utama Konsumen

Pada Gambar 9 memperlihatkan menu utama konsumen yang memiliki 3 submenu yang sudah dirancang di bagian iii yaitu menu cari, menu tips trik dan menu rating.

2. Jasa Binatu 


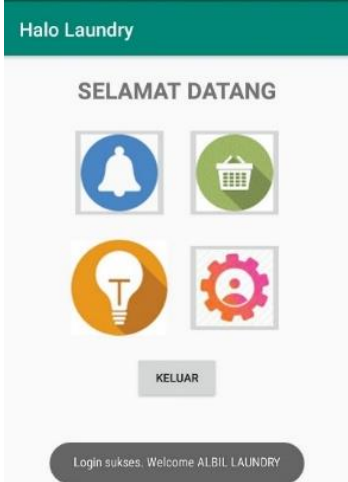

Gambar 10. Menu Utama Jasa Binatu

Pada Gambar 10 menunjukan menu utama jasa binatu sesuai yang dijabarkan pada bagian iii ada 4 submenu yang ditampilkan dan memiliki masing-masing fungsi yang berbeda yaitu menu notice dimana terdapat list konsumen yang meminta atau memesan jasa antar jemput, menu data pemesanan yang berisi list pemesanan yang sedang dikerjakan dengan rinciannya, menu tips trik dan pengaturan pengguna jasa binatu dimana bisa mengatur informasi miliknya.

3. Tampilan Menu-Menu Tambahan

Menu tambahan sebagai variasi yang pertama adalah menu tips dan trik yang ada pada kedua belah pihak. Berfungsi sebagai menu tambahan bagi Pengguna supaya menjadi referensi dalam menyelesaikan permasalahan pakaian.

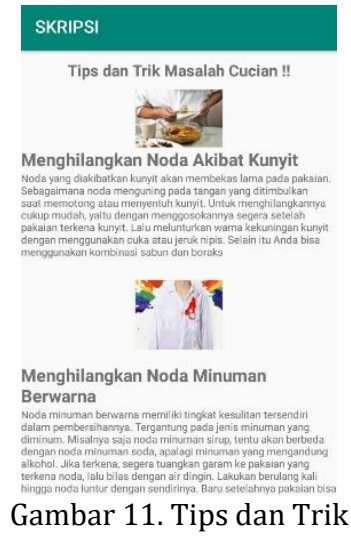

Menu tambahan yang ke dua adalah menu beri rating yang berada di submenu konsumen. Menu yang diinput oleh konsumen dan diberikan kepada jasa binatu atas pelayanan yang diberikan, nantinya akan masuk dan diakumulasi oleh sistem dan dapat ditampilkan sebagai informasi jasa binatu tersebut.

Menu tambahan yang ke tiga adalah menu pengaturan atau setting yang berada di submenu jasa binatu, menu ini menunjukan pengaturan informasi pada jasa binatu yang dapat diedit oleh jasa binatu sendiri. Informasi yang nanti dirubah oleh Pengguna akan disimpan dan merubah informasi pada tampilan di menu konsumen.

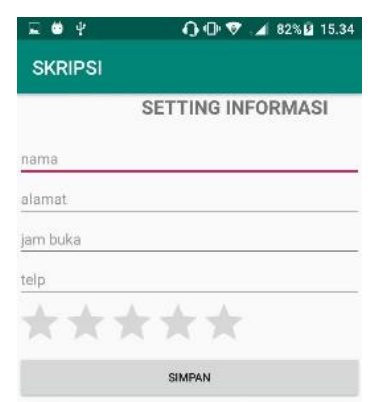

Gambar 12. Setting Jasa Binatu

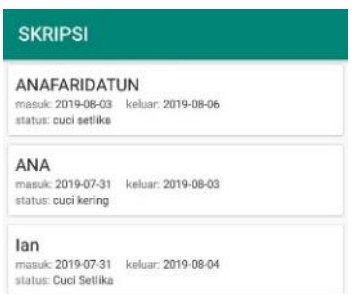

Gambar 13. Tampilan Data Pesanan

Untuk Gambar 13 adalah menu data pesanan yaitu menu yang berisi list-list data pesanan dari setiap pengguna jasa binatu yang sedang dikerjakan. Terdapat nama, tanggal masuk, tanggal keluar dan jenis binatu yang sedang dikerjakan.

\section{Uji Coba Sistem}

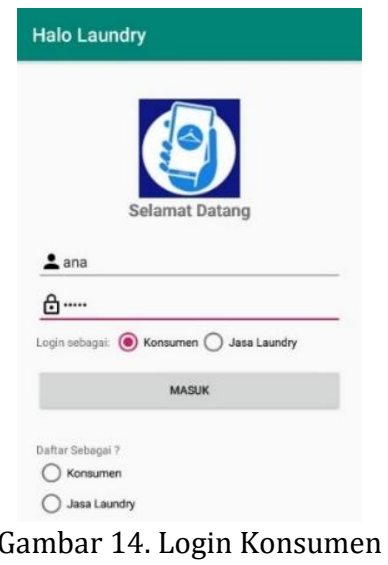

Untuk uji coba aplikasi akan diperlihatkan pada bagian awal yaitu login. Selanjutnya akan menampilkan menu utama konsumen, karena pengguna masuk dan terdaftar sebagai konsumen sebelumnya misal user Ana dengan password 12345 dan memilih konsumen lalu menekan tombol masuk. Jika Pengguna belum terdaftar, maka pilih salah satu dari "Daftar Sebagai", dapat sebagai Konsumen atau Jasa Binatu dimana harus isi registrasi dengan benar.

Selanjutnya masuk pada Menu Utama Konsumen seperti pada Gambar pilih menu "CARI" dengan bentuk icon search maka akan menampilkan hasil pencarian jasa binatu terdekat 
dengan maps. Dapat dilihat pada Gambar 15 Tampilan Maps Jasa Binatu Terdekat.

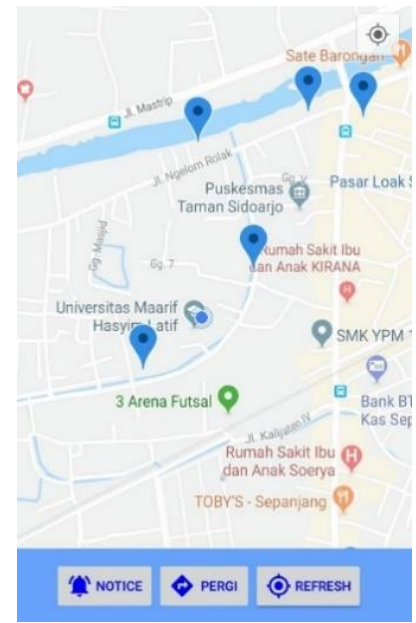

Gambar 15. Tampilan Maps Jasa Binatu Terdekat

Terlihat pada Gambar 15 bahwa lokasi pengguna ada di Universitas Maarif Hasyim Latif Sidoarjo dan mendeteksi lokasi jasa binatu terdekat darinya. Selanjutnya kita pilih salah satu jasa binatu yang kita inginkan maka akan keluar informasi dari jasa binatu tersebut mulai dari nama jasa binatu, nomor telepon, email dan rating.

Tampilan yang akan muncul dapat dilihat pada Gambar 16 Info Jasa Binatu Terpilih. Pada tampilan maps tersebut terdapat menu botton notice, pergi dan refresh dimana memiliki fungsi berbeda. Jika kita memilih notice maka kita akan mengirimkan pemberitahuan kepada jasa binatu terpilih untuk pesan jasa jemput.

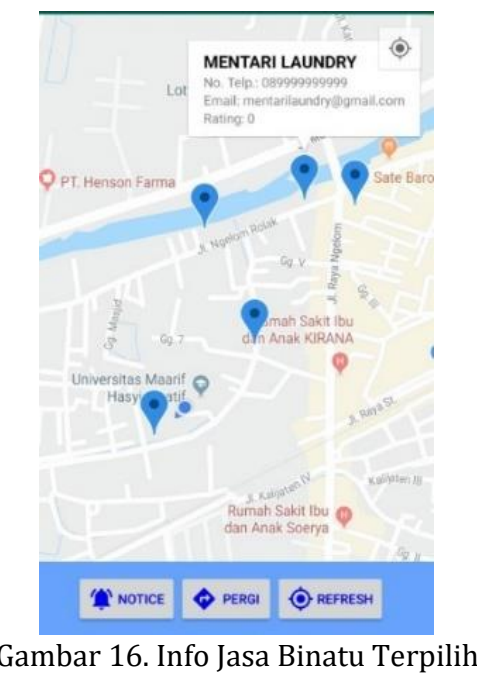

Sistem saat memilih button notice, sistem akan mengirimkan notice dan diterima oleh jasa binatu yang masuk pada submenu dengan icon lonceng. Notice yang dikirim konsumen akan masuk kepada jasa binatu pada submenu jasa binatu dengan icon keranjang sebagai memudahkan jasa binatu dalam mendata, mengelola pesanan yang sedang dikerjakan seperti pada Gambar 13 Data Pesanan.

Untuk button pergi akan masuk pada maps yang mengarahkan kita menuju jasa binatu dengan rute terdekat yaitu metode dijkstra, Dapat dilihat pada Gambar 16 menjelasan mengenai proses sistem jika memilih button pergi. Sistem akan menghitung dan menentukan rute mana yang dapat pengguna gunakan untuk menuju lokasi jasa binatu terpilih dari lokasinya. Proses ini membutuhkan sedikit membutuhkan waktu karena harus menentukan lokasi yang terdekat.

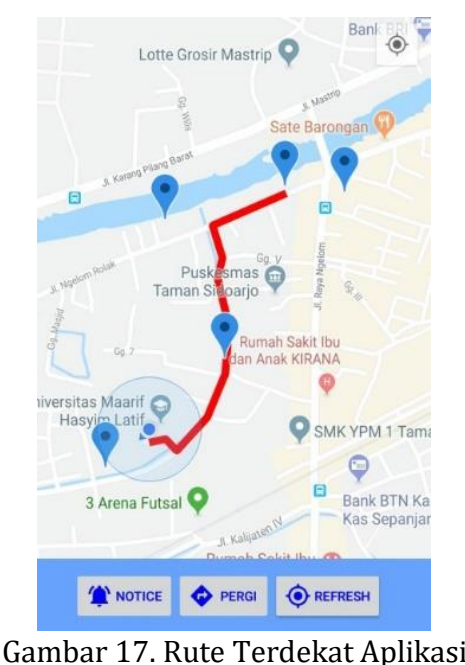

Untuk penjelasan rute terdekat dilihat dari Gambar 17 bahwa lokasi konsumen adalah Universitas Maarif Hasyim Latif Sidoarjo dan menuju lokasi jasa binatu terpilih yaitu Mentari Laundry.

\section{PENUTUP}

Berdasarkan pembahasan dan hasil dari penelitian yang penulis lakukan mulai awal dari login aplikasi sampai mendeteksi lokasi jasa binatu terdekat di sekitar konsumen dapat berjalan dengan baik maka diperoleh beberapa kesimpulan sebagai berikut : (1) aplikasi dijalankan saat login dan registrasi, dapat masuk tersimpan ke sistem; (2) rancangan sistem yang dibuat berhasil dalam membuka dan menentukan lokasi jasa binatu terdekat dari konsumen; (3) pendeteksi lokasi jasa binatu terdekat sudah baik, akan tetapi di dalam penerapan metode dijkstra ,asih perlu penyempurnaan utamanya pada jarak-jarak yang bernilai sama; dan (4) manfaat aplikasi ini dapat diterapkan di masyarakat, dan dikembangkan oleh generasi ke generasi serta berinovasi menjadi lebih baik dan menarik.

Berikut ini adalah saran yang dapat digunakan untuk tahap pengembangan penelitian sistem ini antara lain : agar dapat ditambahkan fiturnya yang lebih banyak lagi pada aplikasi 
supaya semakin menarik dan dapat bermanfaat sesuai harapan. Pada penelitian selanjutnya diharapkan peneliti-peneliti generasi berikutnya dapat memperbaiki segala kekurangan dari penelitian ini.

\section{DAFTAR PUSTAKA}

[1] A. Widyan, "affanw's Blog: Algoritma Dijkstra," 2013. [Online]. Available: http://affanw.blogspot.com/2013/05/algorit ma-dijkstra.html. [Accessed: 19-Jan-2019].

[2] A. M. Afif, R. Wardhani, and Masruroh, "Aplikasi Laundry Online Lamongan Berbasis Android," J-TIIES (Jurnal Tek. Ilmu Lingkungan, Inform. Elektro, Sipil), vol. 1, no. 1, 2017.

[3] D. Ratnasari, D. B. Qur'ani, and A. Apriani, "Sistem Informasi Pencarian Tempat Kos Berbasis Android," Inf. J. Ilm. Bid. Teknol. Inf. dan Komun., vol. 3, no. 1, pp. 32-45, 2018.

[4] C. Ramadhani, Teori Dan Algoritma Graph Dengan Bahasa Java. Yogyakarta: Penerbit Andi, 2019.

[5] M. K. Harahap and N. Khairina, "Pencarian Jalur Terpendek dengan Algoritma Dijkstra," SinkrOn, vol. 2, no. 2, pp. 18-23, 2017.

[6] N. Azizah and D. Mahendra, "Geolocation dengan Metode Djikstra untuk Menentukan Jalur Terpendek Lokasi Peribadatan," J. Sist. Inf. BISNIS, vol. 7, no. 2, p. 96, Nov. 2017.

[7] E. Cahyono, A. Baraja, and C. Naury, "Pembuatan Aplikasi Laundry Online Berbasis GPS Pada Platform Android," Fakultas Teknik Elektro dan Informatika - Universitas Surakarta, Solo, 2017. 
AF Nafiah / Ubiquitous: Computers and its Applications Journal, Vol. 3, No. 2, Desember 2020, 99-106 